\title{
Pengaruh Berbagai Jenis POC dan Dosis PGPR Terhadap Pertumbuhan dan Hasil Tanaman Okra (Abelmoschus esculenthus)
}

\author{
Dian Triadiawarman', Rudi $^{2}$, dan La Sarido ${ }^{3}$ \\ 1,2,3 Program Studi Agroteknologi STIPER Kutai Timur, Kalimantan Timur \\ JIn Soekarno-Hatta, Sangatta, Kutai Timur, Kalimantan Timur, Indonesia \\ 1 Email : diantriadi72@gmail.com
}

\begin{abstract}
Research aimed and examine was to determine the effect of LOF various types and PGPR dosage on growth and yield of okra (Abelmoschus esculenthus). Research was conducted on April up to June 2020 at Agrotechnology farming research of STIPER East Kutai. The factorial pattern design based on randomized block design $(R B D)$ was used, LOF type treatment consisted of 4 treatments, namely: $P 1=L O F$ banana corm, $P 2=L O F$ banana stem, $P 3=L O F$ fruit waste, $P 4=P O C$ coconut husk, and PGPR treatment consists of 4 treatments, namely: $G 1=0 \mathrm{ml} / \mathrm{tt}, \mathrm{G} 2=20$ $\mathrm{ml} / \mathrm{lt}$, G3 $=40 \mathrm{ml} / \mathrm{lt}, \mathrm{G} 4=60 \mathrm{ml} / \mathrm{t}$. All treatments were 3 replicated. Data were analyzed by analysis of variance, if there was a significant effect on the treatment it will be continued by Duncan Multiple Range Test (DMRT) at 5\% significance levels. The observed variable includes of Plant Height (PH), Number of Leaves (NL), Flowering Age (FA) and Fruit Weight (FW). There was an interaction between the LOF type and the PGPR dose treatment only on flowering age variable. The research results showed that the best P2G4 treatment on plant height $(64,70 \mathrm{~cm})$, the best P1G4 treatment on the number of leaves (27 strand), the best P2G4 treatment at flowering age (53 days), the best P4G1 treatment at fruit weight ( 80 grams).

Keywords: Types, PGPR, Okra, Growth, Yield.
\end{abstract}

\begin{abstract}
ABSTRAK
Tujuan penelitian untuk mengetahui dan mengkaji pengaruh berbagai jenis $\mathrm{POC}$ dan dosis PGPR terhadap pertumbuhan dan hasil tanaman okra (Abelmoschus esculenthus). Penelitian dilakukan pada April sampai Juni 2020 di Kebun Percobaan Agroteknologi STIPER Kutai Timur. Rancangan yang digunakan adalah Rancangan Acak Kelompok (RAK), dengan pola faktorial, dimana perlakuan jenis POC terdiri atas 4 perlakuan yaitu : $\mathrm{P} 1=\mathrm{POC}$ Bonggol pisang, $\mathrm{P} 2=\mathrm{POC}$ Batang pisang, $\mathrm{P} 3=$ POC Limbah buah, P4 = POC Sabut kelapa, sedangkan perlakuan PGPR terdiri atas 4 perlakuan yaitu : $\mathrm{G} 1=0 \mathrm{ml} / \mathrm{tt}, \mathrm{G} 2=20 \mathrm{ml} / \mathrm{lt}, \mathrm{G} 3=40 \mathrm{ml} / \mathrm{tt}, \mathrm{G} 4=60 \mathrm{ml} / \mathrm{t}$. Seluruh perlakuan diulang sebanyak 3 kali. Data dianalisis dengan analisis sidik ragam yang dilanjutkan dengan uji Duncan Multiple Range Test (DMRT) pada tingkat signifikasi $5 \%$ bila terdapat pengaruh nyata pada perlakuan. Variabel yang diamati meliputi Tinggi Tanaman (TT), Jumlah Daun (JD), Umur Berbunga (UB) dan Berat Buah (BB). Terjadi interaksi antara perlakuan jenis POC dan dosis PGPR hanya terhadap variabel umur berbunga. Hasil penelitian menunjukkan bahwa perlakuan P2G4 yang terbaik pada tinggi tanaman $(64,70 \mathrm{~cm})$, perlakuan P1G4 yang terbaik pada jumlah daun (27 helai), perlakuan P2G4 yang terbaik pada umur berbunga (53 hari), perlakuan P4G1 yang terbaik pada berat buah (80 gram).

Kata kunci: POC, PGPR, Okra, Pertumbuhan, Hasil.
\end{abstract}

\section{Pendahuluan}

Sejak tahun 1877 tanaman okra telah ditanam di Indonesia terutama di Kalimantan

Barat. Tanaman okra dapat menjadi komoditi pertanian yang memiliki potensi tinggi, sehingga mampu untuk menjadi peluang bisnis yang menguntungkan bagi petani. Buah 
okra yang masih muda memiliki kandungan karbohidrat 1,4\%, kalori 38,9\%, protein $8,30 \%$, lemak 2,05\%, dan kadar air 85,70\% per setiap 100 gram (BPTP, 2018).

Tanaman okra tumbuh pada dataran rendah hingga tinggi dengan kisaran $\mathrm{pH}$ tanah sekitar 4,5-7,5. Tanaman okra mampu tumbuh dengan baik pada tanah bertekstur pasir. Tanaman ini memiliki kandungan bahan mineral seperti kalsium, kalium, seng, fosfor, magnesium, tembaga. Selain itu juga mengandung vitamin A, B, C dan K. Pada setiap per 100 gram okra mentah, terdapat 30 kalori, 7,6 gram karbohidrat, 2 gram protein, 0,1 gram lemak, 3 gram serat, 57 gram magnesium, $21 \mathrm{mg}$ vitamin $\mathrm{C}$, dan $88 \mathrm{mcg}$ asam folat. Kandungan mineral dan vitamin tersebut berdampak baik pada Kesehatan manusia. Kendati demikian tanaman ini kurang disukai karena memiliki lendir dan lengket, apalagi saat dipanaskan (Shidqiyyah, 2018).

Pupuk organik adalah bahan yang mampu meningkatan aktivitas biologi, fisik, dan kimia pada tanah agar menjadi subur dan baik untuk pertumbuhan tanaman. Menurut Sutanto (2002), kandungan unsur hara makro pupuk organik rendah, namun unsur hara mikro yang diperlukan tanaman untuk tumbuh dalam jumlah cukup. Pupuk organic sangat mempengaruhi kondisi fisik, kimia dan biologi tanah. Saat ini sebagian besar petani masih tergantung pada pupuk anorganik karena mengandung beberapa unsur hara dalam jumlah yang banyak. Pupuk organik ada yang berbentuk padat dan cair. Pupuk organik cair memiliki kelebihan yakni unsur haranya lebih mudah diserap oleh tanaman. (Murbandono, 1990 dalam Rahmah et al., 2014)

Menurut Lingga \& Marsono (2003), pupuk organik cair adalah jenis pupuk berbentuk larutan yang berasal dari proses fermentasi bahan-bahan organik, seperti sisa tanaman, kotoran hewan dan manusia. Pupuk organik tidak merusak tanah dan tanaman walau sering digunakan. Bahan organik dari sisa buah dan sayuran adalah bahan baku yang mudah terdekomposisi dan kaya unsur hara. Kandungan selulosa dari bahan organik akan mempengaruhi proses penguraian. Kandungan selulosa yang tinggi, maka semakin lama proses penguraiannya (Purwendro \& Nurhidayat, 2006). Manfaat pupuk organik cair antara lain adalah mampu menyehatkan lingkungan, mampu merevitalisasi produktivitas tanah, mampu menekan biaya produksi, mampu meningkatkan kualitas produk (Infoagribisnis, 2018)

Plant Growth Promoting Rhizobacteria (PGPR) adalah bakteri yang hidup pada akar tanaman. PGPR pertama kali diteliti oleh Kloepper dan Scroth (1982) dalam (Oktaviani \& Sholihah, 2018). Hasil penelitiannya menggambarkan bahwa benih yang diinokulasi dengan bakteri tanah yang mendiami perakaran tanaman akan meningkatkan pertumbuhan tanaman. Akar tanaman adalah tempat terjadinya pertukaran udara, unsur hara, dekomposisi. Bakteri yang mendiami perakaran tersebut hidup secara berkoloni menyelimuti akar tanaman. Untuk tanaman tersebut keberadaan mikroorganisme ini sangat 
penting karena memberi keuntungan pada proses fisiologi tanaman (Distan, 2014). Widodo (2006), menyatakan bahwa Rhizobakteria yang mempunyai kemampuan untuk memacu pertumbuhan tanaman dapat digolongkan ke dalam kelompok PGPR.

Dalam perkembangannya beberapa peneliti telah mengeksplorasi bakteri ini dan mensosialisasikan kepada masyarakat untuk menghasilkan produk pertanian yang berkualitas. Sehingga PGPR mengalami perkembangan yang sangat pesat pada beberapa tahun terakhir (Pratiwi. 2014).

\section{Metode Penelitian}

Penelitian ini dilaksanakan di kebun Percobaan Program Studi Agroteknologi STIPER Kutai Timur, pada bulan April-Juni 2020. Bahan yang digunakan pada penelitian ini adalah sabut kelapa, bonggol pisang, batang pisang, limbah buah, EM 4, gula merah, air, benih okra. Sedangkan alat yang digunakan adalah cangkul, parang, meteran, handtraktor, tali rapiah, kayu ajir, ember, pisau, dan kamera.

Rancangan yang digunakan pada penelitian ini adalah Rancangan Acak Kelompok dengan pola Faktorial, masing-masing perlakuan diulang 3 kali, dengan perlakuan sebagai berikut :

1. Perlakuan Pemberian berbagai jenis POC yaitu:

$\mathrm{PI} \quad=\mathrm{POC}$ Bonggol pisang $150 \mathrm{ml} / \mathrm{tt}$

$\mathrm{P} 2=\mathrm{POC}$ Batang pisang $150 \mathrm{ml} / \mathrm{lt}$

P3 = POC Limbah buah $150 \mathrm{ml} / \mathrm{lt}$

$\mathrm{P} 4=\mathrm{POC}$ Sabut kelapa $150 \mathrm{ml} / \mathrm{tt}$

2. Perlakuan Pemberian PGPR yaitu:

$$
\begin{array}{ll}
\mathrm{G} 1 & =0 \mathrm{ml} / \mathrm{lt} \\
\mathrm{G} 2 & =20 \mathrm{ml} / \mathrm{t} \\
\mathrm{G} 3 & =40 \mathrm{ml} / \mathrm{tt} \\
\mathrm{G} 4 & =60 \mathrm{ml} / \mathrm{t}
\end{array}
$$

Tahapan pelaksanaan penelitian : persemaian benih okra, pengolahan lahan dan pembuatan bedengan, aplikasi pupuk dasar, penanaman bibit okra, aplikasi POC dan PGPR pada umur 14 HST, 28 HST dan 42 HST. Pemeliharaan, Pemanenan.

Data-data yang diperoleh dianalisis secara statistik berdasarkan analisis varian pada setiap peubah amatan yang diukur dan diuji lanjut bagi perlakuan yang nyata dengan menggunakan metode Duncan Multiple Range Test (DMRT) pada taraf 5\%. 


\section{Hasil dan Pembahasan}

Hasil sidik ragam menunjukan bahwa pemberian berbagai jenis POC dan dosis PGPR hanya berpengaruh nyata terhadap Umur Berbunga. Rataan akibat pemberian berbagai jenis POC dan dosis PGPR dapat dilihat pada Tabel 1.

Tabel 1. Pengaruh berbagai jenis $P O C$ dan dosis PGPR terhadap Tinggi Tanaman (TT), Jumlah Daun (JD), Umur Berbunga (UB) dan Berat Buah (BB) Tanaman Okra.

\begin{tabular}{lcccc}
\hline & \multicolumn{5}{c}{ Parameter } \\
\cline { 2 - 5 } Perlakuan & $\begin{array}{c}\text { TT } \\
\text { (cm) }\end{array}$ & $\begin{array}{c}\text { JD } \\
\text { (helai) }\end{array}$ & $\begin{array}{c}\text { UB } \\
\text { (hari) }\end{array}$ & $\begin{array}{c}\text { BB } \\
\text { (g) }\end{array}$ \\
\hline P1G1 & 51,92 & 23 & $113,00 \mathrm{~b}$ & 29 \\
P1G2 & 62,50 & 24 & $166,00 \mathrm{c}$ & 72 \\
P1G3 & 55,00 & 23 & $168,50 \mathrm{c}$ & 48 \\
P1G4 & 60,82 & 27 & $160,75 \mathrm{c}$ & 78 \\
P2G1 & 62,75 & 24 & $107,25 \mathrm{~b}$ & 50 \\
P2G2 & 48,37 & 21 & $104,00 \mathrm{~b}$ & 59 \\
P2G3 & 52,00 & 20 & $104,00 \mathrm{~b}$ & 35 \\
P2G4 & 64,70 & 19 & $53,00 \mathrm{a}$ & 46 \\
P3G1 & 52,62 & 24 & $110,30 \mathrm{~b}$ & 60 \\
P3G2 & 53,67 & 19 & $166,25 \mathrm{c}$ & 57 \\
P3G3 & 59,62 & 25 & $108,25 \mathrm{~b}$ & 44 \\
P3G4 & 52,50 & 18 & $11,50 \mathrm{~b}$ & 45 \\
P4G1 & 61,87 & 23 & $106,50 \mathrm{~b}$ & 80 \\
P4G2 & 52,50 & 19 & $161,75 \mathrm{c}$ & 46 \\
P4G3 & 49,32 & 17 & $115,50 \mathrm{~b}$ & 68 \\
P4G4 & 62,62 & 23 & $110,30 \mathrm{~b}$ & 70 \\
\hline
\end{tabular}

\section{Tinggi Tanaman}

Hasil sidik ragam perlakuan berbagai Jenis POC dan Dosis PGPR menunjukan tidak berpengaruh nyata terhadap rata-rata tinggi tanaman okra.

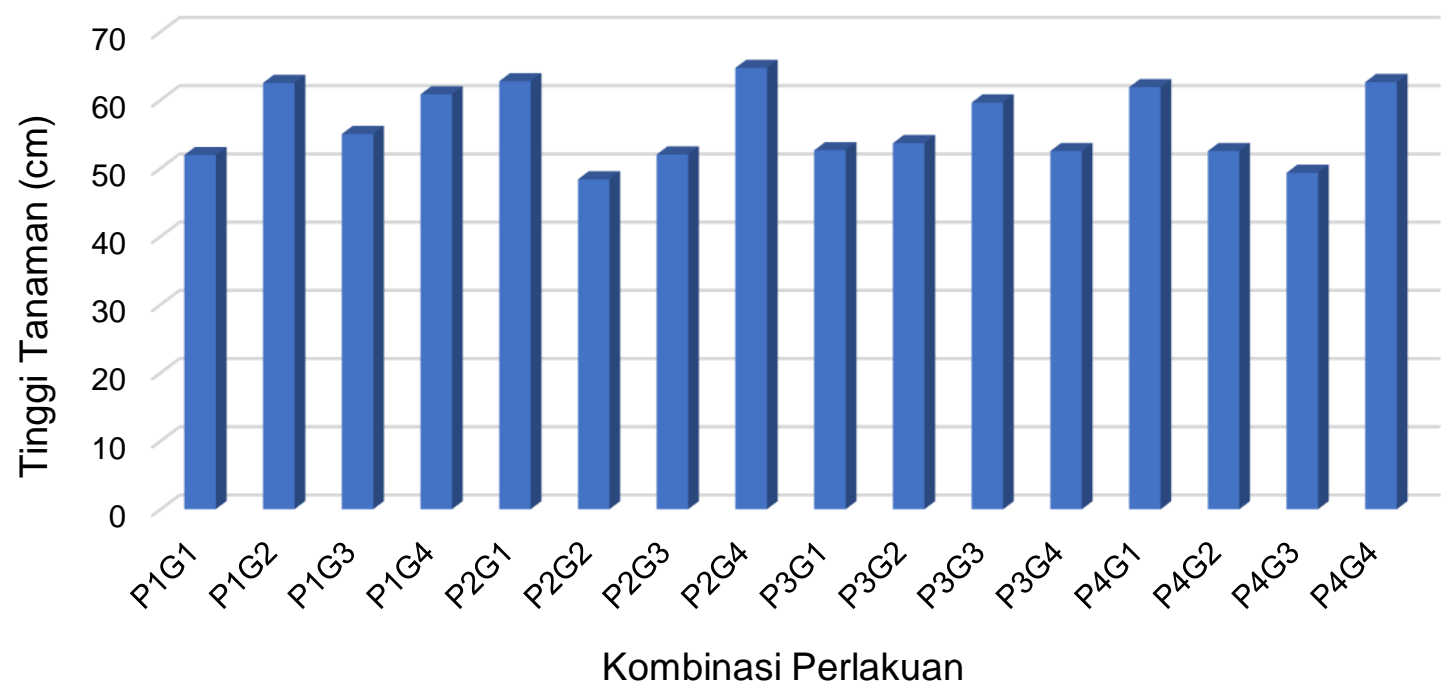

Gambar 1. Diagram Pengaruh Berbagai Jenis POC dan Dosis PGPR Terhadap Pertumbuhan dan Hasil Tanaman Okra (Abelmoschus esculenthus).

Berdasarkan Gambar 1 perlakuan berbagai jenis POC dan Dosis PGPR menunjukan rataan tertinggi pada perlakuan P2G4 sebesar $64,75 \mathrm{~cm}$. Hal ini disebabkan 
POC batang pisang mengandung unsur hara $\mathrm{N}, \mathrm{P}$ dan $\mathrm{K}$ yang dibutuhkan tanaman untuk pertumbuhannya (Ernawati, 2016). Unsur $\mathrm{N}$ dibutuhkan untuk pertumbuhan tanaman, karena unsur $\mathrm{N}$ sangat berperan penting untuk merangsang pertumbuhan tinggi tanaman (Pramitasari et al., 2016). Bertambahnya tinggi tanaman sangat erat kaitannya dengan kandungan unsur hara makro seperti nitrogen. Dengan adanya kandungan unsur nitrogen (N) pada pupuk organik cair dari limbah batang pisang, maka dapat berpengaruh terhadap pertambahan tinggi tanaman okra. Unsur nitrogen $(\mathrm{N})$ berperan dalam merangsang pertumbuhan vegetatif yaitu menambah tinggi. Setyamidjaja (1986) dalam Pramitasari et al., (2016) menyatakan bahwa unsur $\mathrm{N}$ berperan dalam merangsang pertumbuhan vegetatif yaitu menambah tinggi tanaman. Media tanam yang mengandung $\mathrm{N}$ lebih tinggi akan memberikan tinggi tanaman terbaik bila dibandingan dengan media yang kekurangan $\mathrm{N}$ (Fajrin \& Santoso, 2019). Wahyuningsih et al., (2017) menyatakan bahwa PGPR mampu menstimulasi pembentukan IAA dan Giberelin yang berfungsi sebagai pemacu pertumbuhan tanaman. Auksin mempengaruhi pertambahan panjang batang, pertumbuhan, diferensiasi dan percabangan akar; perkembangan buah; dominansi apikal; fototropisme dan geotropisme. Sitokinin dihasilkan pada akar dan berfungsi untuk pertumbuhan dan difrensiasi akar, sehingga diduga hormon inilah yang mempengaruhi terhadap parameter jumlah akar. Wiraatmaja (2017) menyatakan bahwa Giberelin sebagai hormon tumbuh pada tanaman sangat berpengaruh pada sifat genetik (genetic dwarfism), pembuangan, penyinaran, partohenocarpy, mobilisasi karbohidrat selama perkecambahan (germination) dan aspek fisiologi lainnya. Giberelin mempunyai peranan dalam mendukung perpanjangan sel (cell elongation), aktivitas kambium dan mendukung pembentukan RNA baru serta sintesa protein.

\section{Jumlah Daun}

Hasil sidik ragam perlakuan berbagai Jenis POC dan Dosis PGPR menunjukan tidak berpengaruh nyata terhadap rata-rata jumlah daun tanaman okra. 


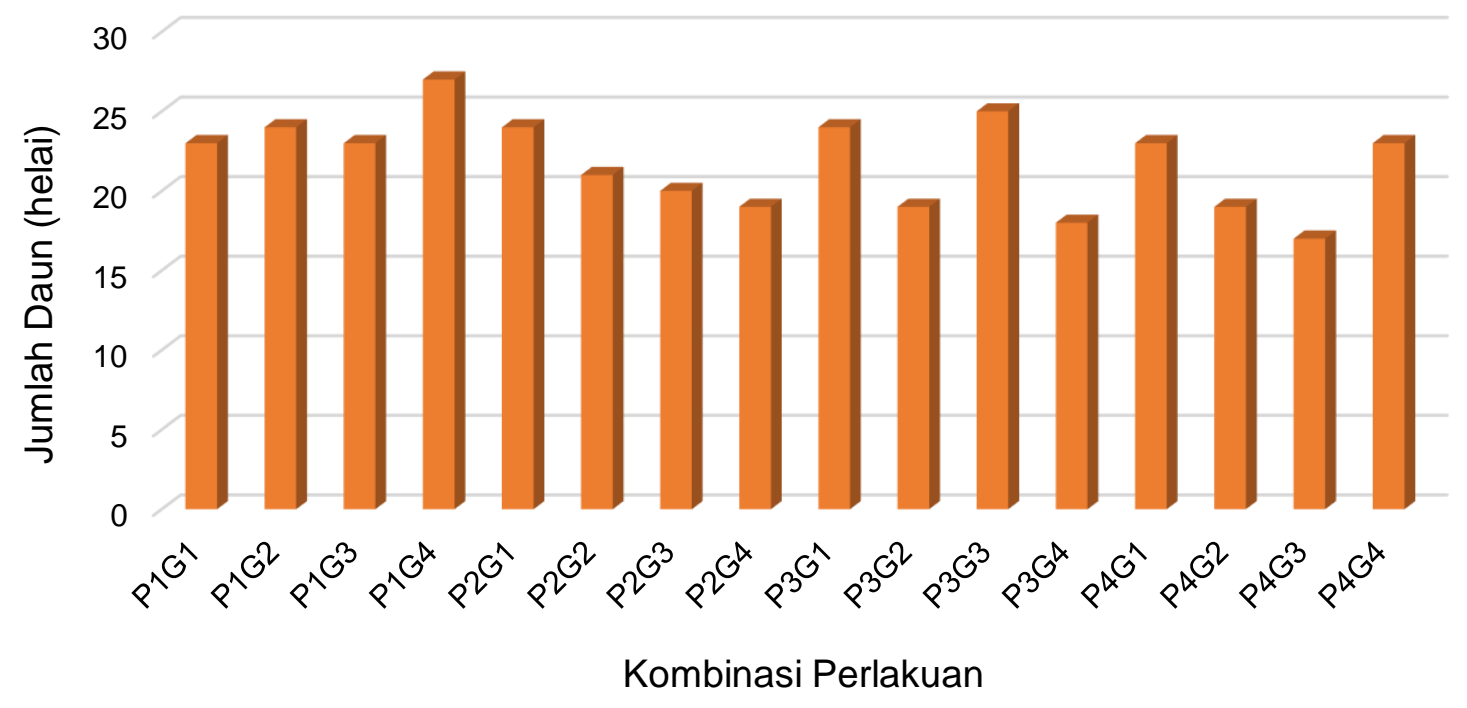

Gambar 2. Diagram Pengaruh Berbagai Jenis POC dan Dosis PGPR Terhadap Pertumbuhan dan Hasil Tanaman Okra (Abelmoschus esculenthus).

Berdasarkan ambar 2 perlakuan berbagai jenis POC dan Dosis PGPR menunjukan rataan tertinggi pada perlakuan P1G4 sebesar 27 helai. Hal ini disebabkan POC bonggol pisang mengandung unsur $\mathrm{N}$ yang cukup dan dosis PGPR yang tepat untuk pertambahan jumlah daun tanaman okra. Hal ini dapat dipengaruhi oleh unsur $\mathrm{N}$ yang terdapat pada bonggol pisang. Unsur $\mathrm{N}$ dapat mempercepat pertumbuhan tunas yang baru pada tanaman okra. Hasil fotosintesa yang berupa senyawa-senyawa organik yang kemudian dibebaskan dalam bentuk ATP untuk pertumbuhan tanaman. Menurut Nasution (2020) manfaat asam fulvat adalah membantu sejumlah aktivitas kimia seperti produksi enzim, struktur hormon dan kebutuhan dalam penggunaan vitamin, meningkatkan pertumbuhan tanaman, perbaikan kesuburan tanah, dapat menyerap logam berat dan racun polutan serta dapat membantu memperbaiki ketidakseimbangan sel. Iswati (2012) bahwa PGPR berperan dalam mempengaruhi pertumbuhaan tanaman tomat terutama dalam memacu pertumbuhan batang, daun maupun akar. pemberian PGPR pada tanaman dengan dosis yang tepat mampu memacu pertumbuhan jumlah daun tanaman yang optimal. Pengaruh dosis PGPR terhadap jumlah daun dan jumlah akar, tampak meningkat secara linier sampai batas tertentu kemudian pengaruh tersebut menurun dengan adanya penambahan dosis. Widodo (2006) menyatakan bahwa bakteri PGPR dapat memberi keuntungan dalam proses fisiologi tanaman dan pertumbuhnya, seperti memproduksi dan mengubah konsentrasi fitohormon pemacu tumbuh tanaman, meningkatkan ketersediaan nutrisi bagi tanaman dengan menyediakan dan memobilisasi atau menfasilitasi penyerapan berbagai unsur hara dalam tanah dan menekan perkembangan hama/penyakit. Wahyuningsih et al., (2017), PGPR mampu menstimulasi pembentukan IAA dan Giberelin yang berfungsi sebagai pemacu pertumbuhan tanaman. Bakteri yang terdapat di dalam PGPR berperan sebagai 
decomposer yang berperan mempercepat proses dekomposisi menjadi bahan organik, yang berguna untuk menyuplai unsur hara bagi pertumbuhan tanaman.

\section{Umur Berbunga}

Hasil sidik ragam perlakuan berbagai jenis POC dan Dosis PGPR menunjukan berpengaruh nyata terhadap rata-rata umur berbunga tanaman okra.

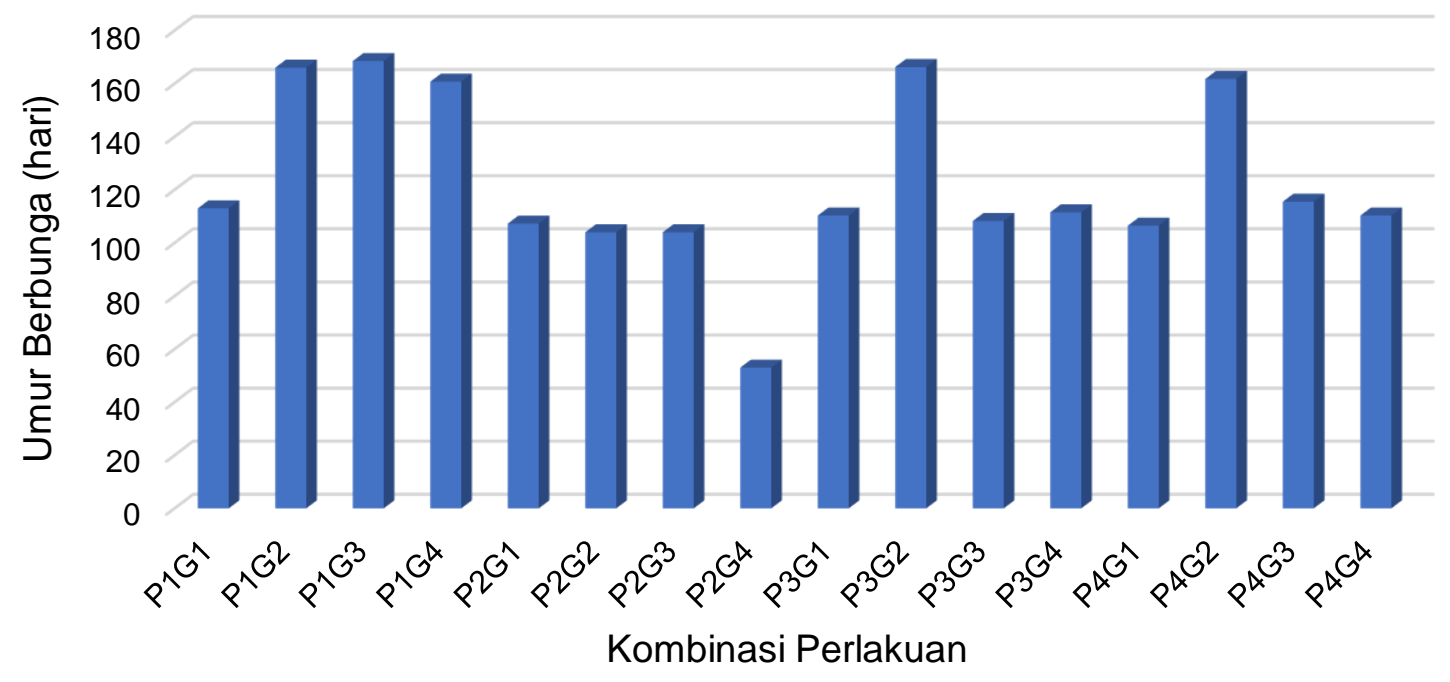

Gambar 3. Diagram Pengaruh Berbagai Jenis POC dan Dosis PGPR Terhadap Pertumbuhan dan Hasil Tanaman Okra (Abelmoschus esculenthus).

Berdasarkan Gambar 3 perlakuan berbagai jenis POC dan Dosis PGPR menunjukan rataan tercepat pada perlakuan P2G4 sebesar 53 hari. Hal ini diduga pada perlakuan tersebut terjadi peningkatan penyerapan unsur $P$ sejalan dengan peningkatan dosis PGPR. Proses pembungaan dipengaruhi oleh Unsur hara P (Fosfor). Unsur N, P, dan $\mathrm{K}$ yang terkandung dalam POC limbah batang pisang dapat mempercepat pembungaan, perkembangan biji dan buah, membantu pembentukan karbohidrat, protein, lemak dan berbagai persenyawaan lainya. Bagi tanaman biji-bijian unsur $\mathrm{P}$ diperlukan untuk mendapatkan pertumbuhan tanaman dan hasil panen yang optimal. Jika kandungan fosfor dan kalium tidak optimal maka pembentukan buah akan berkurang. Menurut Sutedjo (2008) bahwa unsur hara berupa $\mathrm{N}, \mathrm{P}$, dan $\mathrm{K}$ sangat diperlukan untuk pertumbuhan vegetatif dan generatif tanaman. Unsur $\mathrm{N}$ diperlukan untuk pembentukan karbohidrat, protein, lemak dan persenyawaan organik lainnya. Unsur $P$ berperan dalam pembentukan bagian generatif tanaman. Hal ini sesuai dengan pendapat (Advinda, 2018) yang menyatakan bahwa fosfor berperan dalam proses metabolisme energi menghasilkan ATP yang digunakan pada proses pembungaan. Unsur $\mathrm{P}$ adalah komponen dari penyusun membran sel tanaman, penyusun enzim-enzim, penyusun co-enzim, nukleotida sintesis karbohidrat dan memacu pembentukan bunga. Sehingga saat proses pembungaan kebutuhan unsur $P$ akan sangat meningkat karena kebutuhan energi meningkat. Kartasapoetra dan Sutedjo (2015) dalam 
(Pratama, 2019) menyatakan bahwa fosfor bermanfaat untuk percepatan pembungaan dan pemasakan buah, serta meningkatakan produksi biji-bijian.

\section{Berat Buah}

Hasil sidik ragam perlakuan berbagai jenis POC dan Dosis PGPR menunjukan tidak berpengaruh nyata terhadap rata-rata berat buah tanaman okra.

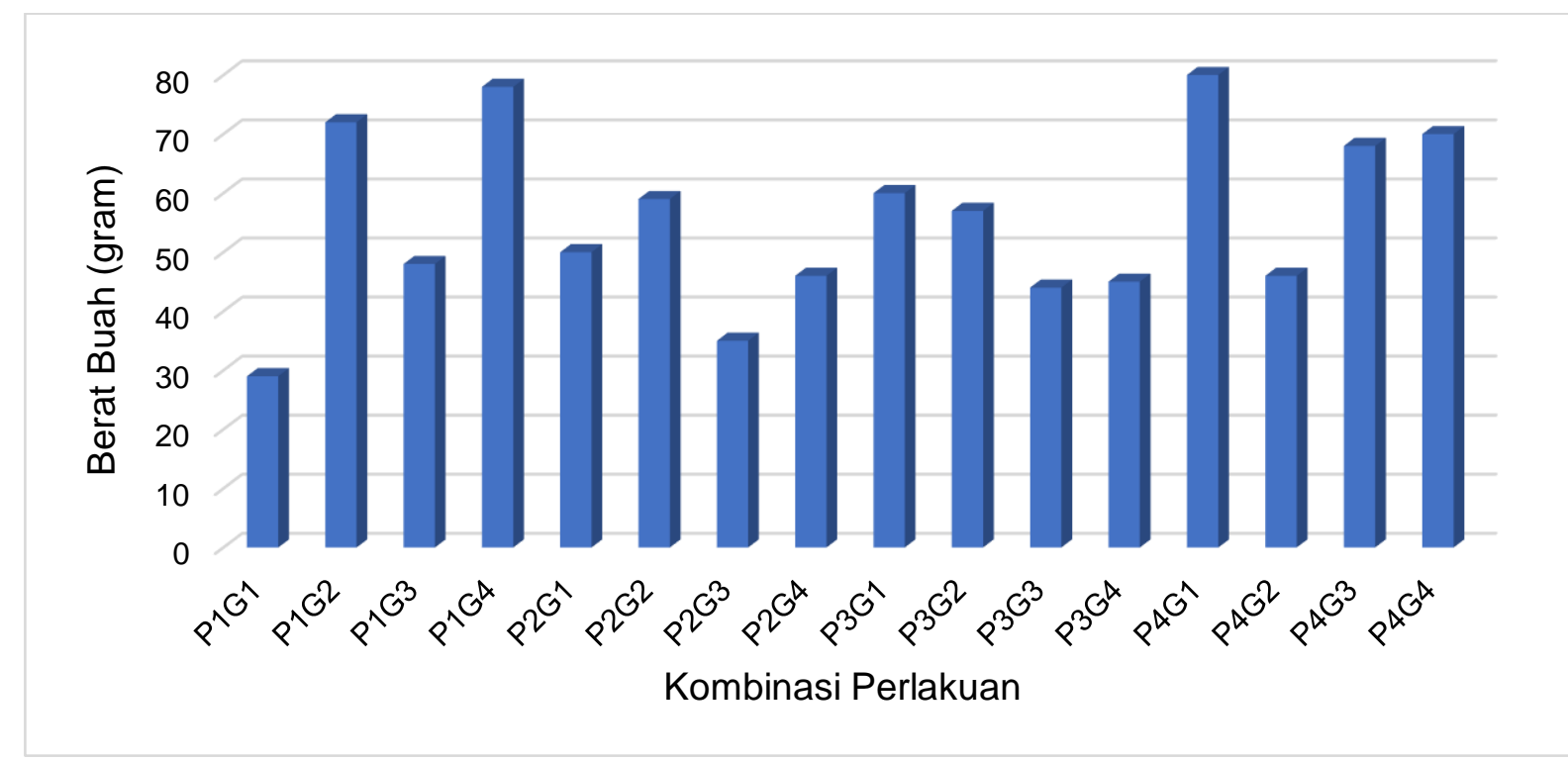

Gambar 4. Diagram Pengaruh Berbagai Jenis POC dan Dosis PGPR Terhadap Pertumbuhan dan Hasil Tanaman Okra (Abelmoschus esculenthus).

Berdasarkan Gambar 4 perlakuan berbagai jenis POC dan Dosis PGPR menunjukan rataan tertinggi pada perlakuan P4G1 sebesar 80 gram. Hal ini diduga POC serabut kelapa mampu memenuhi kebutuhan unsur hara makro untuk masa berbuah tanaman okra. Pemberian pupuk organic cair serabut kelapa sangat mempengaruhi pertumbuhan tanaman okra pada fase vegetatif. Unsur hara N, P dan $\mathrm{K}$ yang tersedia dalam jumlah yang optimal dan seimbang akan mampu memberikan keseimbangan hara makro bagi tanaman okra. Sabut kelapa dapat menjadi sumber alternativ unsur hara makro organik untuk menggantikan pupuk kimia. Menurut Sari (2015), apabila dilakukan proses perendaman serabut kelapa, kalium dalam serabut kelapa tersebut dapat larut dalam air sehingga menghasilkan air rendaman yang mengandung unsur K. Air hasil rendaman yang mengandung unsur $\mathrm{K}$ tersebut sangat baik jika diaplikasikan sebagai pupuk. Unsur hara Makro dan mikro yang terdapat pada sabut kelapa yaitu: K, P, Ca, Mg, Na dan beberapa mineral lainnya (Isknews, 2016). POC serabut kelapa memberikan berat buah tertinggi karena unsur N, P, dan K serta unsur lain yang terkandung di dalam POC serabut kelapa dapat diserap oleh tanaman okra sehingga proses fotosintesis dapat berjalan lebih optimal. Menurut Prasetya (2014), semakin dewasa umur tanaman maka sistem perakaran telah berkembang dengan baik, sehingga tanaman semakin mampu menyerap berbagai unsur 
hara yang terkandung dalam tanah, sehingga berdampak pada peningkatan pertumbuhan dan perkembangan tanaman.

\section{Kesimpulan}

Perlakuan POC dan dosis PGPR terdapat interaksi hanya pada umur berbunga. Perlakuan P2G1 yang terbaik pada tinggi tanaman, perlakuan P1G4 yang terbaik pada jumlah daun. Perlakuan P2G4 yang terbaik pada umur berbunga dan perlakuan P4G1 yang terbaik pada berat buah.

\section{Daftar Pustaka}

Advinda, L. (2018). Dasar-Dasar Fisiologi Tumbuhan. Yogyakarta: Deepublish.

BPTP Jakarta. (2018). Mengenal Tanaman Okra yang Kaya Manfaat. Retrieved from Balai Pengkajian Teknologi Pertanian Jakarta website: http://jakarta.litbang.pertanian.go.id/ind/index.php/publikasi/artikel/1096-mengenaltanaman-okra-yang-kaya-manfaat.

Ernawati, E. (2016). Pengaruh Pemberian Kompos Batang Pisang Kepok (Musa acuminate balbissiana Colla) Terhadap Pertumbuhan Tanaman Terung Ungu (Solanum melongena L.) dan Sumbangsihnya Pada Miswatiateri Pertumbuhan dan Perkembangan Di SMA/MA Kelas XII. 13 Maret 2020. http://eprints.radenfatah.ac.id/eprint/1474.

Fajrin, M., \& Santoso, M. (2019). Pengaruh Media Tanam dan Pengaplikasian PGPR (Plant Growth Promoting Rhizobacteria ) terhadap Pertumbuhan dan Hasil Tanaman Okra (Abelmoschus esculentus L.) Jurnal Produksi Tanaman, 7(4), 681-689.

Info Agribisnis. (2018). Beragam Manfaat Pupuk Organik Cair. Retrieved from https://www.infoagribisnis.com/ website: https://www.infoagribisnis.com/2018/02/manfaat-pupuk-organik-cair/\#: :text=Secara umum berikut keunggulan dan,jika dibandingkan dengan pupuk anorganik.\&text=Kandungan unsur hara makro dan,water holding capasity yang tinggi.

ISK News. (2016). Sabut Kelapa Sebagai Sabut Kelapa Sebagai Sumber Hara Kalium Organik. Retrieved from https://isknews.com/ website: https://isknews.com/sabutkelapa-sebagai-sumber-hara-kalium-organik/

Iswati, R. (2012). Pengaruh Dosis Formula PGPR Asal Perakaran Bambu terhadap Pertumbuhan Tanaman Tomat (Solanum lycopersicum syn ). Jurnal Agroteknotropika, 1(1), 2006-2009.

Lingga, P. \& Marsono. (2003). Petunjuk Penggunaan Pupuk. Jakarta: Penebar Swadaya.

Nasution, N. (2020). Pengertian Asam Humat Dan Asam Fulvat Serta Manfaatnya Untuk Tanaman. Retrieved from Cybext website: http://cybex.pertanian.go.id/mobile/artikel/90842/Pengertian-Asam-Humat-DanAsam-Fulvat-Serta-Manfaatnya-Untuk-Tanaman/

Oktaviani, E., \& Sholihah, S. M. (2018). Pengaruh Pemberian Plant Growth Promoting Rhizobacteria (PGPR) Terhadap Pertumbuhan dan Hasil Tanaman Kailan (Brassica oleraceae var. acephala) Sistem Vertikultur. Jurnal Akrab Juara, 3(1), 63-70. 
ISSN 2354-7251 (print)

Pramitasari, H. E., Wardiyati, T., \& Nawawi, M. (2016). Pengaruh Dosis Nitrogen dan Tingkat Kepadatan Tanaman Terhadap Pertumbuhan dan Hasil Tanaman Kailan ( Brassica oleraceae L .). Jurnal Produksi Tanaman, 4, 49-56.

Prasetya, M. E. (2014). Pengaruh Pupuk NPK Mutiara dan Pupuk Kandang Sapi Terhadap Pertumbuhan dan Hasil Tanaman Cabai Merah Keriting Varietas Arimbi (Capsicum annuum L.). Jurnal AGRIFOR, XIII(2), 191-198.

Pratama, R. A. (2019). Aplikasi Benzyl Amino Purine (BAP) Dan Plant Growth Promoting Rhizobacteria (PGPR) Terhadap Produksi Edamame (Glycine max (L.) Merrill). Jurnal Agrowiraloda. 2(1), 23-28.

Pertiwi, D. A. A. (2014). Apakah PGPR itu? Retrieved from Dinas Pertanian Daerah Istimewa Yogyakarta website: http://distan.jogjaprov.go.id/apakah-pgpr-itu/

Purwendro, S. \& Nurhidayat. (2006). Mengolah Sampah untuk Pupuk Pestisida Organik. Jakarta: Penebar Swadaya.

Rahmah, A., Izzati, M., \& Parman, S. (2014). Pengaruh Pupuk Organik Cair Berbahan Dasar Limbah Sawi Putih (Brassica chinensis L.) Terhadap Pertumbuhan Tanaman Jagung Manis. Anatomi Dan Fisiologi, XXII(1), 65-71. 20 Mei 2020. https://doi.org/10.14710/baf.v22i1.7810

Sari, S. Y. (2015). Pengaruh Volume Pupuk Organik Cair Berbahan Dasar Serabut Kelapa (Cocos nucifera) Terhadap Pertumbuhan dan Hasil Panen Sawi Hijau (Brassica juncea). Universitas Sanata Dharma, Yogyakarta.

Shidqiyyah, S. (2018). 13 Manfaat Okra Untuk Kesehatan yang Jarang Diketahui, Anti Kanker dan Turunkan Kolesterol. Retrieved from Liputan 6 website: https://www.liputan6.com/health/read/3695648/13-manfaat-okra-untuk-kesehatanyang-jarang-diketahui-anti-kanker-dan-turunkan-kolesterol

Sutanto, R. (2002). Pupuk dan Cara Pemupukan. Jakarta: Rieneka Cipta.

Sutedjo, M. M. (2008). Pupuk dan Cara Pemupukan. Jakarta: Rieneka Cipta.

Wahyuningsih, E., Herlina, N., \& Tyasmoro, Y. (2017). Pemberian PGPR ( Plant Growth Promoting Rizhobacteria ) dan Pupuk Kotoran Kelinci Terhadap Pertumbuhan dan Hasil Tanaman Bawang Merah (Allium ascalonicum L.). Jurnal Produksi Tanaman, 5(4), 591-599.

Widodo. (2006). Peran mikroba bermanfaat dalam pengelolaan terpadu hama dan penyakit tanaman. Makalah disampaikan pada Apresiasi Penanggulangan OPT Tanaman Sayuran, Nganjuk, 3-6 Oktober 2006.

Wiraatmaja, I. W. (2017). Bahan Ajar, Zat Pengatur Tumbuh Giberelin Dan Sitokinin. Program Studi Agroteknologi, Fakultas Pertanian Universitas Udayana. 24 Juli 2020. https://simdos.unud.ac.id/uploads/file_pendidikan_1_dir/e917f35423a841cab64616e 33b90778c.pdf. 